\title{
MUSCULAR INFANTILISM
}

\author{
ALEXANDER GIBSON, M.B. \\ WINNIPEG, CANADA
}

Diseases of the nervous system form a somewhat obscure branch of medical science. Our ignorance of the morbid anatomy and histology of many of them is profound. It is, accordingly, a matter of no surprise that our classification of these diseases is unsatisfactory. The intimate correlation between nervous and muscular systems is recognized in the fact that under nervous diseases, every textbook includes descriptions of conditions which are, so far as known, essentially muscular.

There is a tendency to segregate those cases which show muscular atrophy into two clinical groups, the atrophies and the dystrophies. The distinction is probably not well grounded, in respect to etiology. In view, however, of our lack of knowledge of the cause of most of the nueuromusclar diseases, even this criticism must be made somewhat tentative. We can recognize the grosser caluses of lack of function of the central nervous system, such as cerebral hemorrhage, or an attack of meningitis, but we know very little of the factors which maintain the central nervous system as a going concern; even in the case of the much simpler muscular system there are many unsolved conundrums. Why is creatin always present in muscle? Does it originate in muscle or is it carried from the outside? What mechanism in the muscle transforms it into creatinin, and what is the value of this apparently essential substance in the muscular economy? With the nervous element in the neuromuscular complex remaining shrouded in mystery, there is little cause for wonder that such comparatively common conditions as disseminated sclerosis, progressive muscular atrophy, or pseadohypertrophic paralysis, remain unexplained.

The essence of scientific experiment is to vary one factor at a time, the others remaining constant. In the case of the human subject, it is difficult, almost impossible, to predicate these conditions, but an approximation to them in which there is one outstanding clinical variation from normal and along with it one outstanding chemical variation from normal has come under notice. In the belief that it is a valuable case I venture to place it on record.

\section{REPORT OF CASE}

R. W. T., aged 26, single, bank clerk, consulted me Sept. 25, 1917, because of his inability to perform any unusual exertion, or, in fact, anything more than a comparatively small muscular effort would accomplish. There was no history of tiring easily; provided, the muscular work called for was small in 
intensity, the effort could be maintained as long as it could be by the ordinary person, but when the effort called for was more than a very small amount, it simply could not be performed. Thus he could walk about all day, and perform to the full his duties as a bank clerk; he could enjoy a game of golf, but

TABle 1.-Patient's Family History on Father's Side

\begin{tabular}{|c|c|c|}
\hline $\begin{array}{l}\text { "Dad's" } \\
\text { Grandmother, } \\
\text { affected }\end{array}$ & $\begin{array}{c}\text { 1. Female, } \\
\text { affected, } \\
\text { "Dad's" mother }\end{array}$ & 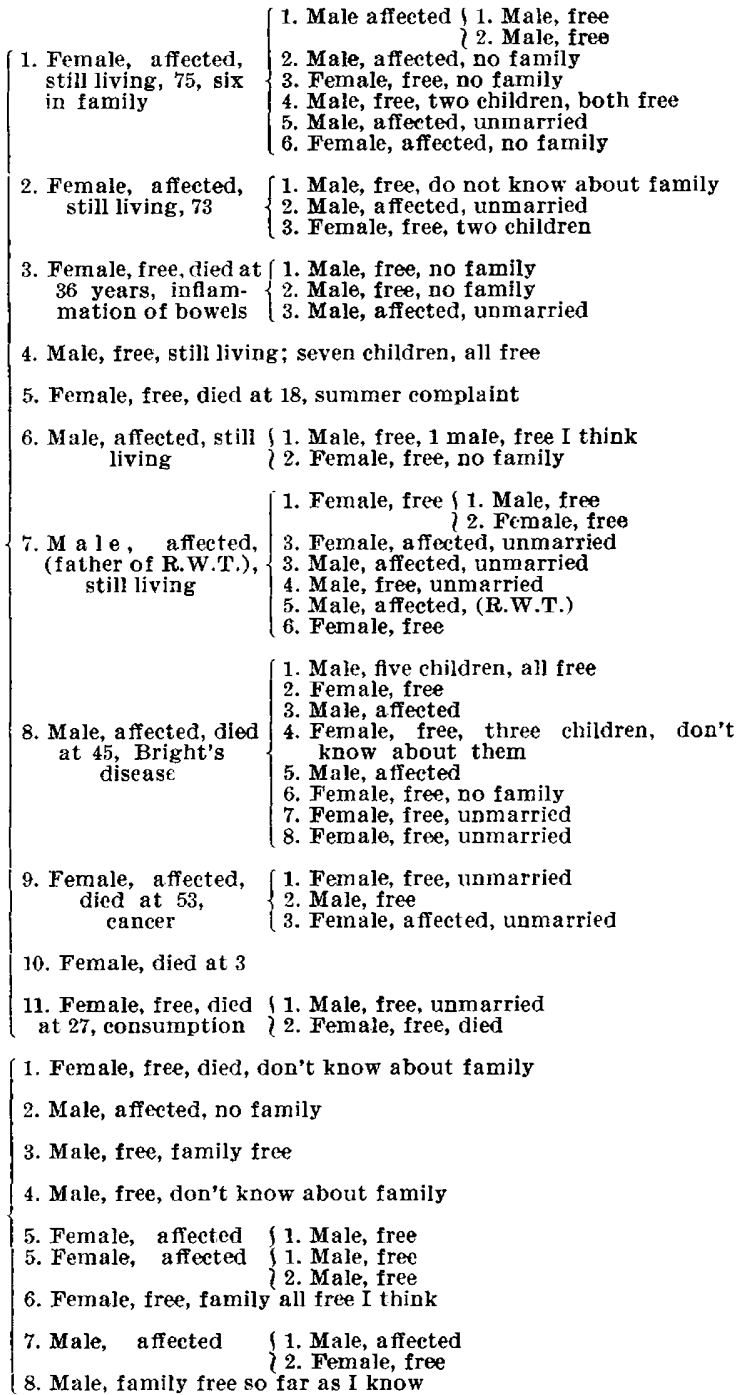 \\
\hline
\end{tabular}

throwing a baseball or rowing a boat were sheer impossibilities, while even such ordinary activities as taking a high step or rising from a sitting to the upright position without the assistance of his hands, were difficult. He had been aware of this condition since he was a child. His health has always been good, and within limits his enjoyment of physical activity has always been 
as great as that of his neighbors. The physical limitation has never been associated with mental weakness or psychic change of any sort, apart from the recognition that his muscular weakness handicapped him in juvenile sports. He knows that his father, and his father's mother have the same weakness.

Family History.-It was possible to obtain a fairly complete family history, dating back to the patient's paternal great grandmother, and passing down through his paternal grandmother and his father to himself. From a study of Table 1 it will be seen that the condition affects both male and female, that with one exception-if the observation be correct-those who are themselves free from the condition, whether male or female, do not transmit it to their children. That exception is the third oldest of "Dad's" sisters, who while free herself bad a son who is affected. This individual, my patient states, is much the worst of all, being "pretty helpless." It further shows that the condition is not one which predisposes to any particular disease, does not of itself shorten life, and in no way interferes with the reproductive powers. Analysis of Table 1 shows further that of twenty-six males liable to be affected, fourteen were so affected, and twelve were free. Of twenty-one females, seven were affected while fourteen were free.

TABle 2.-Physical Measurements of Patient

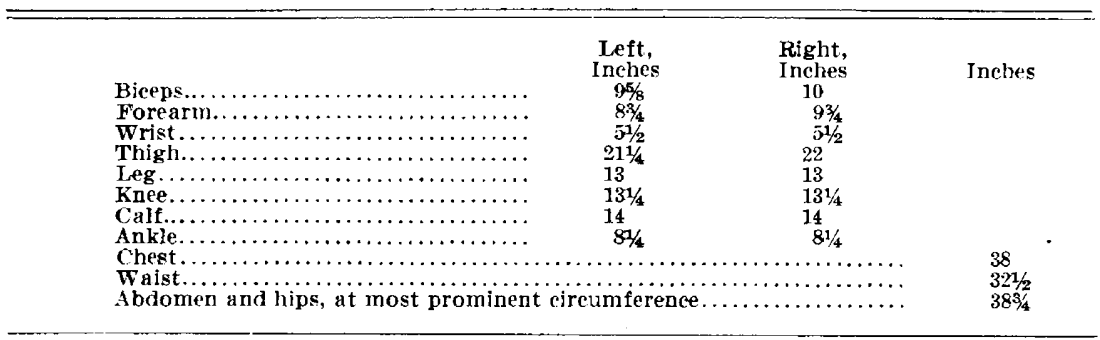

Physical Examination,-Examination shows apparently little departure from the normal. The patient is 5 feet 8 inches tall and weighs 155 pounds. $\mathrm{He}$ is distinctly adipose, the fat being largely distributed in the general subcutaneous tissue. so that there are rounded outlines suggestive of the female rather than the male figure. This suggestion is accentuated by the presence of striae over the lower abdomen and upper part of the thighs, some of these being white and glistening, others purplish, exactly like typical "striae gravidarum." $\mathrm{He}$ has no recollection when these appeared. He underwent no sudden or even rapid increase in bulk, and is not now thinner than he has been, so that the explanation of the striae is somewhat obscure. This relative adiposity is, the patient states, not characteristic of the condition. He is himself, he says, the only one he knows of who shows it. The majority of those affected are normal in outline, all, however, being characterized by the presence of small bones. The probability is that the smallness of the bones is directly correlated with the limited power of the muscles. The wrist measurement, for example, in this case is about $5 \frac{1}{2}$ inches. The average female wrist is about 6 inches, and the average male wrist is about $63 / 4$ inches.

Two other characteristics of those affected are the presence of distinctly square shoulders and a short neck. ${ }^{1}$

1. A fairly complete examination has been made from time to time, and in this respect I am indebted to Professor Swale Vincent, of the Department of Physiology, University of Manitoba, now of the University of London, to Professor William Boyd of the Department of Pathology, University of Manitoba, and to Dr. Robert G. Armour of Toronto, for observation along special lines. 
Examination of the circulatory, respiratory and alimentary systems revealed no abnormality. The blood pressure (systolic) has varied ftom 130 to 140 . The urine has shown no alloumin, blood, sugar or pus. The thyroid is very slightly enlarged.

Blood Examination.-Investigation of the blood was done from time to time. The red cell count has always been above normal, varying from $6,230,000$ to $5,760,000$. The leukocyte count has always been about normal, the highest observation being 12,400, the lowest 7,600. The hemoglobin is also within the limits of normal variation, from 75 to 90 per cent. being the limits. This, it will be observed, gives a rather lower color index than normal.

The differential leukocyte count has followed at all times strictly normal lines, averaging: polymorphonuclears, 75 per cent.; small lymphocytes, 20 per cent.; large lymphocytes, 3 per cent.; eosinophils, 2 per cent.

Roentgen-Ray Examination.-Roentgenograms were taken of the skull with a view to determining whether or not there was any increase in the size of the pituitary fossa. No variation from normal has been observed.

Examination of the Central Nervous System.-This examination was made at my request by Dr. Robert G. Armour of Toronto. His report is as follows:

Feb. 5, 1919: Shoulders broad and high; pelvis narrow; musculature of thighs apparently good, tapering markedly from hips to knees; calves well developed; musculature of arms poor, about size of those of boy of 16; no obvious wasting of any particular muscle or group; fingers moderately small and tapering, not deformed; toes slightly "hammer"; in standing, appear to spread. $\mathrm{He}$ has always had trouble in getting boots to fit him on account of the width of the feet at the base of the toes. Marked callosities under transverse arch of feet. Station, with eyes closed, good. On either leg alone and eyes closed, fair. On left not quite so steady as on right. Tends to trip or slip easily. Gets up from a lying position fairly readily, with no attempt to "climb up" himself. Can walk on toes, but has difficulty in rising on heels. No appearance of atrophy of peroneal muscles. Moderately good strength of leg muscles, although below average, and low in proportion to appearance of development. Strength of biceps and triceps of arms inconsiderable.

Grasp of hands each 16 on dynamometer (average normally 45). No inequality in strength of facial muscles of two sides. Retraction of mouth not well performed, and extreme efforts cause little wrinkling of the face. No apparent weakness of upper face. Mouth opened and tongue protruded, and palate elevated to full extent and in middle line. No ptosis. Eye movements full in all directions. No nystagmus. Pupils react briskly to light and accommodation. Fundi normal. Moderate pes cavus.

Reflexes: Knee jerk present, easily elicited, not increased, no clonus. Idiomuscular contractility not obtained over quadriceps extensor. Ankle jerk easily elicited, no clonus, equal, idiomuscular contractility obtained in calf muscles. Attempts to elicit this in extensors and peroneals cause contraction of the calf muscles which raise the heel from the ground. When this is prevented, no idiomuscular contractility is obtained. Biceps and triceps reflexes of upper extremity easily elicited. Idiomuscular contractility present in triceps, extensors of forearms and doubtful in deltoids. Not present in biceps, pectorals or trapezii. Present to a slight degree in the facial muscles. Plantar, plantat flexion, but feeble. Cremasteric reflex doubtful. Abdominal and epigastric reflex doubtful.

No sensory change demonstrable, including position sense. No tachycardia. All muscles react to faradism.

Examination of the Eyes.-This examination was made for me by Dr. Harvey Smith. His report is: "I find that he has a small error of refraction. Fundus examination is negative, nor can I discover any defect in his field or in his pupillary reflexes."

The Wassermann reaction was negative. There was slight enlargement of the thyroid gland.

Treatment.-At the suggestion of Professor Swale Vincent, raw suprarenal glands were administered. One ox gland per day was taken, minced, as a sand- 
wich, commencing Nov. 1, 1917. This was continued until Dec. 18, 1917, when because of some nausea this feeding was stopped. Ergographic tracings made before and after the administration of suprarenal gland seemed to indicate slight improvement in the muscular condition, but it was not striking.

Jan. 25, 1918, suprarenal gland feeding was resumed at the rate of one-half ox gland per day. This was continued until March 14, 1918. No appreciable increase of muscular power was noted, although there was some gastric instability. The taking of suprarenal gland was, therefore, definitely stopped.

May 17, 1918, a course of graduated exercises was commenced. These were of a simple nature designed with a view to increasing the existing muscular development. They were continued until June 26, 1918, when there was added to the exercises a course with the Bristow coil, an instrument which in other cases has proved of considerable value in increasing the bulk of atrophied muscles.

Oct. 15, 1918, his measurements were again taken.

Table 3.-Physical Measurements Eleven Months After Treatment Was Begun

\begin{tabular}{|c|c|c|c|}
\hline 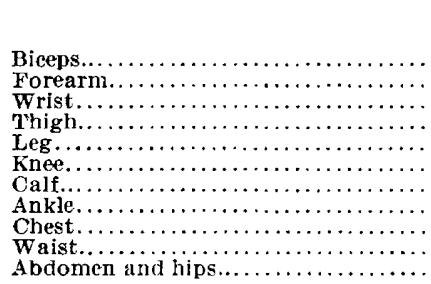 & $\begin{array}{l}\text { Left, } \\
\text { Inches } \\
10 \\
91 / 8 \\
51 / 2 \\
217 / 8 \\
13 \% 8 \\
131 / 2 \\
14 \\
73 / 8\end{array}$ & $\begin{array}{l}\text { Right, } \\
\text { Inches } \\
10^{1 / 8} \\
9 \% / 8 \\
51 / 2 \\
22 \\
133 / 8 \\
131 / 2 \\
141 / 2 \\
7 \% / 8\end{array}$ & $\begin{array}{l}38 \\
33 \\
391 / 2\end{array}$ \\
\hline
\end{tabular}

These measurements are confirmatory of the opinion expressed by him that his muscular power was little, if any, increased.

Subsequent Course.- In the spring of 1919, the patient had an attack of 'influenza and was ill for three weeks. The summer he spent at work in the country and I did not see him again until Sept. 22, 1919. The measurements then were as follows:

Table 4.-Physical Measurements Eleven Months After Cessation of Treatment

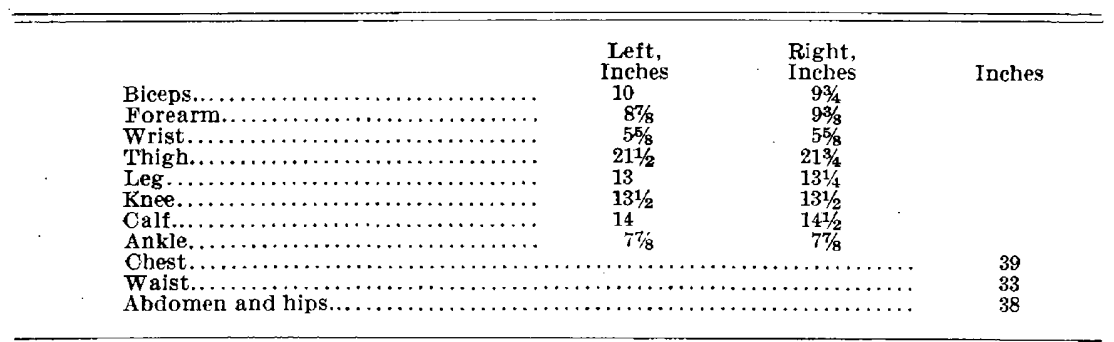

These show practically no alteration from those previously noted. In other words, he seemed to be as well without treatment of any sort as with it.

The muscles themselves, though not at all massive, are not, abnormally small for a man of his build. The electrical reactions were tested and gave a response 'of normal quality to both faradism and galvanism. A small piece of muscle was excised from the right vastus lateralis muscle and sent for histologic 
examination to Professor William Boyd. His report indicates practically no departure from the normal.

Microscopic Examination.-Portions of the vastus lateralis muscle, removed under local anesthesia, were examined by the usual methods. The only marked deviation from the normal was the wide separation of the muscle fibers from one another by what appeared to be edematous fluid. This, however, was probably merely the result of the injection of novocain. The individual muscle fibers appeared to be slightly atrophic, but the transverse striations were quite distinct, although, perhaps, not quite so prominent as in the normal fibers. The nuclei of the sarcolemma were well developed. There was no evidence of any of the increase of fat which is so characteristic a feature of the pseudohypertrophic form of muscular dystrophy.

From April 20, 1920, until June 6, 1920, thyroid gland was given, 15 grains per day. During treatment with thyroid gland he had an excess of carbohydrate. The result of this was certainly not an improvement clinically, and examination of the urine suggests that the results were bad. Pituitary extract. 15 grains per day was taken from June 14, 1920, until July 7, 1920. Again no improvement was shown. Strychnin, 3/55 grain, was also used from Sept. 13, 1920 , until Sept. 20, 1920, with equally unfavorable consequences.

From time to time the patient has been examined by Prof. Swale Vincent and by Prof. A. T. Cameron. Professor Vincent's report is as follows:

March, 1920: The patient has a fairly good power of long sustained effort of a low grade. He walks fairly well and can play eighteen holes of golf without much fatigue. He can raise a 25 pound bar above his head four or five times. He can hang onto a horizontal bar for a moment, but cannot raise himself in the least. There has been some increase in the strength of his arms since 1917.

The dynamometer record has also slightly improved since 1917 . The results have varied between 40 and 50 kilograms tested by Verdin's (Boulitte's) dynamometer. Mosso's ergograph has not given very accurate results because of the long time during which the patient could continue minimal contractions. With the right second finger the laboratory attendant could execute $400 \mathrm{kilogram}$ centimeters of work when each complete movement was carried out in two seconds. The patient could only raise the weight five or six times, doing at most from 12 to 15 kilogram centimeters of work. Roughly, then, his muscular power is about 4 or 5 per cent. of the normal.

\section{CHEMICAL REPORT}

The observations have been carried out between March and October. 1920. As during this period the patient was carrying out his usual duties, it was impossible to conduct an exact supervision of diet. As soon as the creatinuria was definitely associated with his condition, futher observations were directed chiefly to the effect of treatment on this symptom. As the degree of creatinuria did not appear to be materially affected by a moderate meat diet, no special diet conditions were imposed, but full particulars were obtained of the nature of the meals on the days on which twenty-four hour urine samples were obtained.

Urine Examination. - The following methods were employed: The total phosphates were estimated by the uranium acetate method. Chlorids were estimated by the Volhard-Arnold method. Uric acid was determined by the Benedict-Hitchcock modification of the Folin-Macallum-Denis procedure. Acidity and total ammonia and amino-acids were estimated by the formol titration method. Creatin and creatinin were determined by the Folin-Benedict method, using a Kober colorimeter. The creatin figures are expressed in terms of creatinin. Urea was approximately determined by the Hinds-Doremus ureometer.

Nothing specially abnormal was observed in the color, appearance or specific gravity. Indican was only present in normal amounts. The acetone bodies (tested for by Le Nobel's, Gerhardt's, Hurtley's, and Rothera's reactions) were almost invariably absent. The exceptions are noted. Reducing sugar and albumin were invariably absent. Urinary sediments were not abnormal. 
The figures in Table 5 refer to grams in the twenty-four hour sample, except those for acidity, expressed in cubic centimeters of tenth normal alkali.

May 9, an extremely hot day, more water than usual was drunk, less urine than usual was excreted, and the Le Nobel and Gerhardt tests for aceto-acetic acid, and the Rothera test for acetone were distinctly positive. June 11, the Rothera test was positive, the Le Nobel test just positive, and the Gerhardt test negative.

TABLE 5.-Results of Examination of Urine

\begin{tabular}{|c|c|c|c|c|c|c|c|c|c|c|c|}
\hline Date & $\begin{array}{l}\text { Total } \\
\text { Vol- } \\
\text { ume } \\
\text { in } \\
\text { C.e }\end{array}$ & $\underset{\text { ity }}{\text { Acid- }}$ & $\begin{array}{l}\text { Am- } \\
\text { monia } \\
\text { and } \\
\text { Amino- } \\
\text { Acids }\end{array}$ & Urea & $\begin{array}{l}\text { Uric } \\
\text { Acid }\end{array}$ & $\begin{array}{l}\text { Phos- } \\
\text { phates }\end{array}$ & $\begin{array}{l}\text { Chlor- } \\
\text { ids }\end{array}$ & $\begin{array}{c}\text { Creat- } \\
\text { inin }\end{array}$ & $\begin{array}{l}\text { Creat- } \\
\text { inin } \\
\text { plus } \\
\text { Crea- } \\
\text { tin }\end{array}$ & $\underset{\text { tin }}{\text { Crea- }}$ & Dict \\
\hline $3 / 2$ & 1,050 & 252 & 0.43 & 22 & 0.43 & 2.56 & $\ldots \ldots$ & 1.09 & 1.47 & 0.38 & $\begin{array}{c}\text { Normal; sone roust } \\
\text { beef }\end{array}$ \\
\hline $3 / .9$ & 2,250 & 445 & 0.82 & 27 & 0.51 & 2.41 & 9.27 & 0.81 & 1.72 & 0.91 & $\begin{array}{l}\text { Meatless on March } 8 \\
\text { and } 9\end{array}$ \\
\hline $3 / 31$ & 1,725 & $64 \%$ & 1.12 & $1 \grave{1}$ & $\cdots$ & $\cdots$ & 16.58 & 0.90 & 1.31 & 0.41 & $\begin{array}{l}\text { Normal; meat with } \\
\text { two meals }\end{array}$ \\
\hline $4 / 16$ & 1,785 & 512 & 0.94 & 32 & $\ldots$ & 2.4 & $\ldots$ & 1.45 & 1.80 & 0.35 & Normal: some fish \\
\hline $4 / 17$ & 1,345 & 439 & 0.92 & 30 & $\ldots$ & 2.1 & $\ldots \ldots$ & 1.26 & 1.84 & 0.58 & Meat with two meals \\
\hline $4 / 18$ & 2,040 & 414 & 0.81 & 28 & $\cdots$ & 1.9 & $\ldots$ & 1.22 & 1.71 & 0.49 & Somewhat less meat \\
\hline $4 / 27$ & 1,445 & $\cdots$ & $\cdots$ & $\cdots$ & $\cdots$ & 2.05 & $\cdots$ & 0.90 & 1.52 & 0.62 & $\begin{array}{l}\text { Meatless, th y r o id } \\
\text { from April 20; with } \\
\text { excess sugar }\end{array}$ \\
\hline $5 / 7$ & 1,575 & 431 & 0.63 & 28 & $\cdots$ & $\cdots$ & $\ldots$ & 0.85 & 1.70 & $0.8 \overline{5}$ & $\begin{array}{l}\text { Some fish; thyroid; } \\
\text { sugar }\end{array}$ \\
\hline $5 / 8$ & 1,250 & 393 & 0.75 & 21 & $\cdots$ & $\cdots$ & $\cdots$ & 0.90 & 1.30 & 0.40 & $\begin{array}{l}\text { Meatless; thyroid; su- } \\
\text { gar }\end{array}$ \\
\hline $5 / 9$ & 790 & 458 & 0.78 & 21 & $\cdots$ & . $\cdots$ & & $0.8 \overrightarrow{5}$ & 1.42 & 0.57 & $\begin{array}{l}\text { Some meat; thyroid; } \\
\text { sugar }\end{array}$ \\
\hline $6 / 4$ & 1,300 & 1830 & 1.80 & 21 & $\cdots$ & 2.4 & & 1.14 & $1 . \pm 4$ & 0.10 & $\begin{array}{l}\text { Meatless; thyroid; su- } \\
\text { gar }\end{array}$ \\
\hline $6 / 5$ & 1,350 & 945 & 2.12 & 22 & $\cdots$ & 2.4 & & 1.12 & 1.28 & 0.16 & $\begin{array}{l}\text { Meatless; thyroid; su- } \\
\text { gar }\end{array}$ \\
\hline $6 / 6$ & 1,240 & 840 & 1.42 & 22 & $\cdots$ & 2.4 & & 0.95 & 1.24 & 0.29 & $\begin{array}{l}\text { Chicken; thyroid; su. } \\
\text { gar }\end{array}$ \\
\hline $6 / 11$ & 1,440 & 499 & 1.04 & 30 & 0.78 & $\cdots$ & & 1.48 & 2.20 & 0.72 & $\begin{array}{l}\text { Fish and meat; thy- } \\
\text { roid stopped since } \\
\text { June } 6 \text {; excess of su- } \\
\text { gar continued }\end{array}$ \\
\hline $6 / 29$ & 1,300 & 343 & 0.58 & 21 & $\cdots$ & $\cdots$ & $\cdots \cdots$ & 1.09 & 1.52 & 0.43 & $\begin{array}{l}\text { Some meat; pituitary } \\
\text { and excess sugar } \\
\text { since June } 23\end{array}$ \\
\hline $\begin{array}{l}6 / 30 \\
7 / 1\end{array}$ & $\begin{array}{l}1,470 \\
1,750\end{array}$ & $\begin{array}{l}448 \\
266\end{array}$ & $\begin{array}{l}0.81 \\
0.62\end{array}$ & $\begin{array}{l}21 \\
18\end{array}$ & $\cdots$ & $\cdots$ & $\ldots \ldots$ & $\begin{array}{l}1.04 \\
0.81\end{array}$ & $\begin{array}{l}0.59 \\
1.16\end{array}$ & $\begin{array}{l}0.55 \\
0.35\end{array}$ & $\begin{array}{l}\text { As previous day } \\
\text { As previous day }\end{array}$ \\
\hline $8 / 27$ & 1,050 & $\cdots$ & $\cdots$ & $\cdots$ & $\ldots$ & $\cdots$ & … & 1.33 & 1.89 & 0.56 & $\begin{array}{l}\text { No treatment; some } \\
\text { flsh }\end{array}$ \\
\hline $\begin{array}{l}8 / 28 \\
8 / 29\end{array}$ & $\begin{array}{l}1,320 \\
1,145\end{array}$ & $\cdots$ & $\cdots \cdot$ & $\ddot{m}$ & $\cdots$ & $\cdots$ & & $\begin{array}{l}1.33 \\
0.94\end{array}$ & $\begin{array}{l}1.85 \\
1.25\end{array}$ & $\begin{array}{l}0.52 \\
0.31\end{array}$ & $\begin{array}{l}\text { As previous day } \\
\text { Meatless }\end{array}$ \\
\hline $9 / 19$ & 1,095 & 245 & 0.60 & $\therefore$ & $\cdots$ & $\ldots$ & ..... & 0.89 & $1.3 i$ & 0.48 & $\begin{array}{l}\text { Some meat; strychnln } \\
\text { since September } 13\end{array}$ \\
\hline $9 / 30$ & 1,870 & 274 & 0.75 & . & $\cdots$ & $\cdots$ & .... & 0.82 & $1.2 \bar{i}$ & 0.45 & As prevlous day \\
\hline $9 / 21$ & 1,760 & 289 & 0.62 & . & $\cdots$ & $\cdots$ & $\ldots$. & 0.86 & 1.21 & 0.35 & $\begin{array}{l}\text { As previous day, but } \\
\text { strychnin stoppeil } \\
\text { September } 20\end{array}$ \\
\hline
\end{tabular}

While the urea figures are distinctly low, the only distinct abnormality is the continual presence of creatin. The creatinin excretion for a man of about $68 \mathrm{~kg}$. with some body fat should be about $1.4 \mathrm{gm}$. per day. The figure in Table 5 is almost always less, and is only three-fourths of this on a meatless diet. There is some indication that the excretion of creatin tends to diminish slightly on a meatless diet, though the results for meatless days include the highest figure recorded. The creatin figures are consistently high, varying between 40 and 110 per cent. of the creatinin figures.

Administration of thyroid with excess cane sugar caused for several weeks an increase in the amount of creatin, in agreement with the observation of Cramer and Krause that thyroid medication causes creatinuria, and the occurrence of creatinuria in exophthalmic goiter. Continued administration of thyroid over a prolonged period, while apparently increasing the creatinin toward 
a normal figure, and giving the lowest degree of creatinuria recorded, produced marked acidity, with a concomitant feeling of the patient that he was not so fit, and a distinct decrease of muscular strength, as indicated by the ergograph, so that the initial rise of creatin can be regarded as indicating an adverse effect. The cause of the marked hyperacidity was not ascertained. It was not due to increase of phosphates, nor to acetone bodies nor to lactic acid.

Pituitary produced no effect. Strychnin appeared to decrease the creatinin without producing any effect on the creatin. This effect can, perhaps, be regarded as nonbeneficial, in line with the general effect on the patient and the ergographic record.

In order to study the creatinuria more closely, the urine was collected at three hour intervals on Sunday, September 5. A final collection was made for the nine hour period ending at 8 a. m. September 6 . In this, as in previous work, the patient's accuracy had to be relied on. The total amount passed was very low, but assurance was given that the amount was collected accurately. The diet was meatless, otherwise normal, and the patient had been undergoing no special treatment for the previous two months. The results are shown in Table 6.

TABle 6.-Results of Study of Urine with Patient on a Meatless Diet and Under no Special. Treatment

\begin{tabular}{|c|c|c|c|c|c|c|c|c|c|}
\hline Time & $\begin{array}{c}\text { Volume, } \\
\text { C.e. }\end{array}$ & $\begin{array}{c}\text { Acidity } \\
\text { C.e. }\end{array}$ & $\begin{array}{l}\text { Ammonia } \\
\text { Plus } \\
\text { Amino- } \\
\text { Acids, } \\
\text { Gm. }\end{array}$ & $\begin{array}{l}\text { Creat- } \\
\text { inin, } \\
\text { Ǵm. }\end{array}$ & $\begin{array}{c}\text { Creatin, } \\
\text { Gm. }\end{array}$ & $\begin{array}{c}\text { Acidity } \\
\text { per } \\
100 \mathrm{C} . c .\end{array}$ & $\begin{array}{l}\text { Ammonia } \\
\text { Plus } \\
\text { Amino- } \\
\text { Acids, } \\
\text { Gm.per } \\
\text { 100 C.c. }\end{array}$ & $\begin{array}{l}\text { Creat- } \\
\text { inin, } \\
\text { Gm.per } \\
100 \text { C.c. }\end{array}$ & $\begin{array}{l}\text { Creatin, } \\
\text { Gm, per } \\
100 \text { C.c. }\end{array}$ \\
\hline $\begin{aligned} 11 & \text { a. } \mathrm{m} . \\
2 & \text { p. } \mathrm{m} . \\
5 & \text { p. } \mathrm{m} . \\
8 & \text { p. } \mathrm{m} . \\
11 & \text { p. } \mathrm{m} . \\
8 & \text { a. } \mathrm{m} .\end{aligned}$ & $\begin{array}{r}180 \\
100 \\
85 \\
72 \\
44 \\
215\end{array}$ & $\begin{array}{r}41 \\
35 \\
31 \\
34 \\
31 \\
150\end{array}$ & $\begin{array}{l}0.081 \\
0.077 \\
0.069 \\
0.069 \\
0.053 \\
0.294\end{array}$ & $\begin{array}{l}0.15 \\
0.11 \\
0.12 \\
0.08 \\
0.06 \\
0.27\end{array}$ & $\begin{array}{l}0.09 \\
0.04 \\
0.05 \\
0.05 \\
0.03 \\
0.19\end{array}$ & $\begin{array}{l}93 \\
41 \\
37 \\
47 \\
71 \\
70\end{array}$ & $\begin{array}{l}0.073 \\
0.077 \\
0.081 \\
0.096 \\
0.121 \\
0.137\end{array}$ & $\begin{array}{l}0.08 \\
0.11 \\
0.14 \\
0.11 \\
0.14 \\
0.13\end{array}$ & $\begin{array}{l}0.05 \\
0.04 \\
0.05 \\
0.07 \\
0.07 \\
0.06\end{array}$ \\
\hline Total & 696 & 322 & 0.69 & 0.79 & 0.37 & & 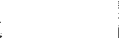 & & \\
\hline
\end{tabular}

These results, especially when expressed per 100 c.c. of urine, indicate that the creatin concentration in the urine is approximately constant throughout the twenty-four hours, but tends to increase slightly with increased acidity and ammonia. The creatinin figures do not show this relationship. This constant excretion of urine throughout the twenty-four hours is not in accordance with other observations on cases of creatinuria. It will be discussed further elsewhere.

Blood Sugar.-Blood sugar was estimated April 2. A sample was taken in the morning, before breakfast. One-tenth per cent. glucose was present (Benedict's modification of the Lewis and Benedict method). A breakfast was given consisting of 200 c.c. of milk, $100 \mathrm{gm}$. bread and butter, and $100 \mathrm{gm}$. glucose. After two hours the blood sugar was 0.15 per cent. The urine contained no reducing sugar throughout the day, and the feces contained none on this nor on the two succeeding days.

Sugar Tolerance.-April 11, two hours after a moderate breakfast, a similar sugar meal was given, with cane sugar substituted for glucose. No reducing sugar was detectable in the urine throughout the day. The carbohydrate metabolism was, therefore, apparently normal.

Blood Creatinin and Creatin.-A sample of blood was obtained Nov. 28, 1920, two hours after breakfast. The creatinin estimated by Folin's method, amounted to $0.7 \mathrm{mg}$. per 100 c.c. blood. This is the minimal figure for normality. The creatin was not determined, since according to Hunter and Camp- 
bell ${ }^{2}$ and Feigl ${ }^{3}$ the present methods do not yield results sufficiently accurate to warrant any conclusions being drawn. A sample of urine obtained at the same time showed, per 100 c.c., $113 \mathrm{mg}$. creatinin and $46 \mathrm{mg}$. creatin.

It may be noted that the blood appears to clot somewhat more readily than normal.

Comment.-Most of the interest of Professor Cameron's report centers around the presence of creatinuria. In considering the results of examination, one must bear in mind the fact that during the whole time of observation the patient has been engaged in his ordinary work. Modifications of diet were for the most part carried out without control. The patient has lent himself to investigation in the most willing and intelligent manner.

The chemical findings may be summarized as follows:

1. The creatinin excretion suggests the actual extent of musculature which he possesses.

2. The creatin excretion suggests an infantile condition.

3. The creatin + creatinin excretion is in agreement with the musculature of a normal individual of his build.

4. The creatin excretion varies little on meat diet.

5. The blood sugar is normal.

6. Sugar utilization is normal.

7. Acetone bodies were present on one occasion only. The creatin for this day was not a maximum. Acetone bodies have no special relation to this condition.

Regarding the influence of treatment it may be said that:

1. During suprarenal administration no chemical examination was made, Professor Cameron being still on active service.

2. During thyroid administration excessive carbohydrate was used without obviously modifying the thyroid effect. (a) There was initially a slight increase in creatin which lasted two or three weeks. (b) After six weeks there was a marked fall in creatin and no appreciable change in creatinin. (c) There was marked acidity of the urine, cause undetermined.

3. Pituitary had no effect. This was noted in spite of carbohydrate being still used in excess.

4. Strychnin apparently decreased creatinin without any marked effect on creatin. This was accompanied by unfavorable ergographic records. Subjectively, the physical condition was also less satisfactory. (Other factors may have entered here to contribute to this.)

Result of a twenty-four hour test on meatless diet was:

1. Creatin was excreted constantly.

2. There was no particular relation to creatinin.

2. J. Biol. Chem. 33:169, 1918.

3. Biochem. Ztschr. 105:255, 1920. 
3. There was increase of creatin with increase of ammonia and acidity.

4. Creatin excretion did not fall off during the night.

5. The kidneys removed creatin from the blood at a fairly constant rate per c.c. of urine.

A word or two is necessary regarding the ergographic tracings. The earlier ones are comparatively valueless on account of the fact

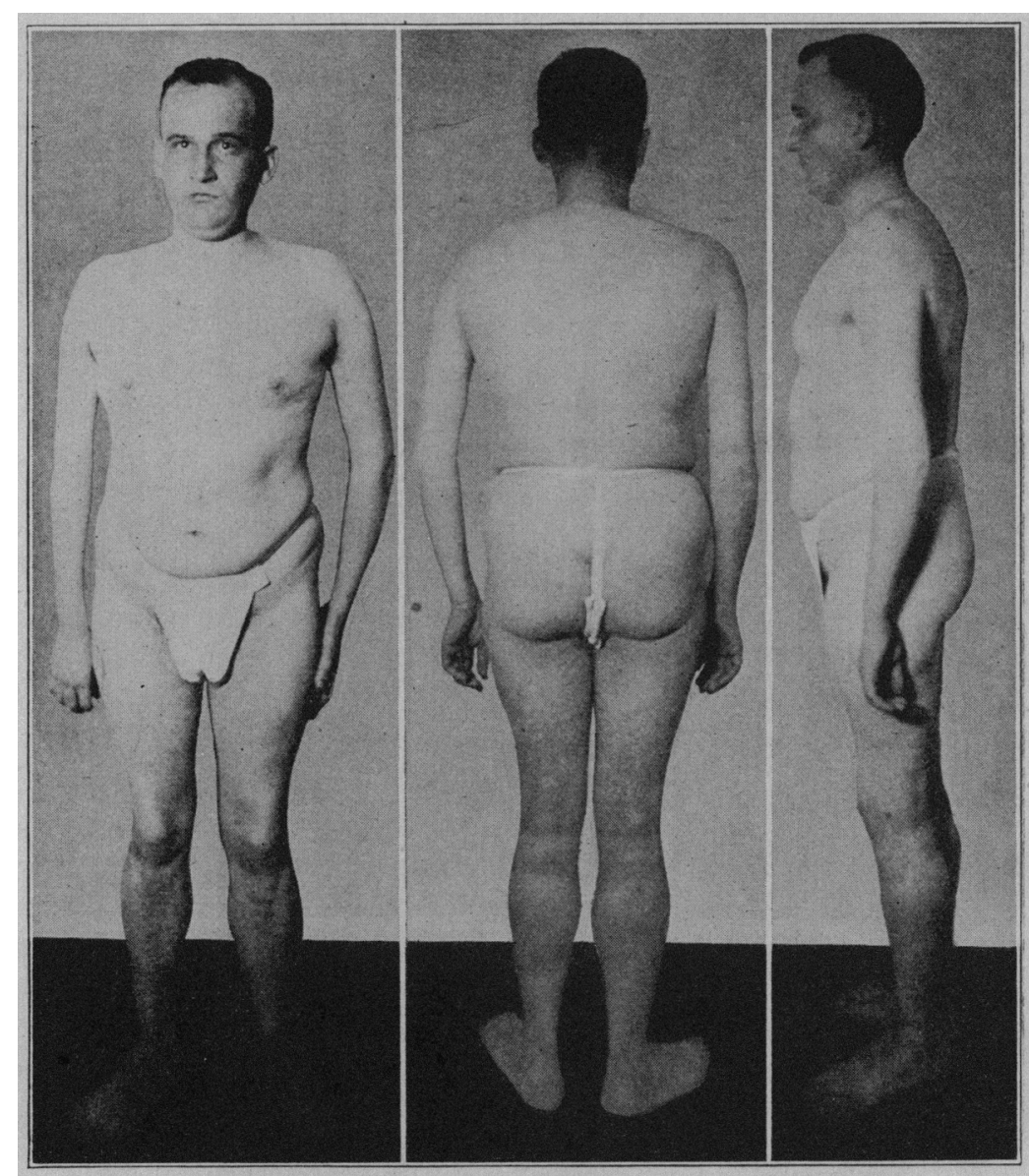

Fig. 1.-Three views of patient showing amount and deposition of fat.

that a small load was used; the patient was able to raise this almost indefinitely; in other words, for a small load his endurance was considerable. In this respect the tracing is infantile in character.

In the later tracings a load of $2,000 \mathrm{gm}$. was used and in most cases the observation was controlled by a corresponding observation on the laboratory attendant. In every case, the load was $2,000 \mathrm{gm}$. and each complete movement was carried out in two seconds. 


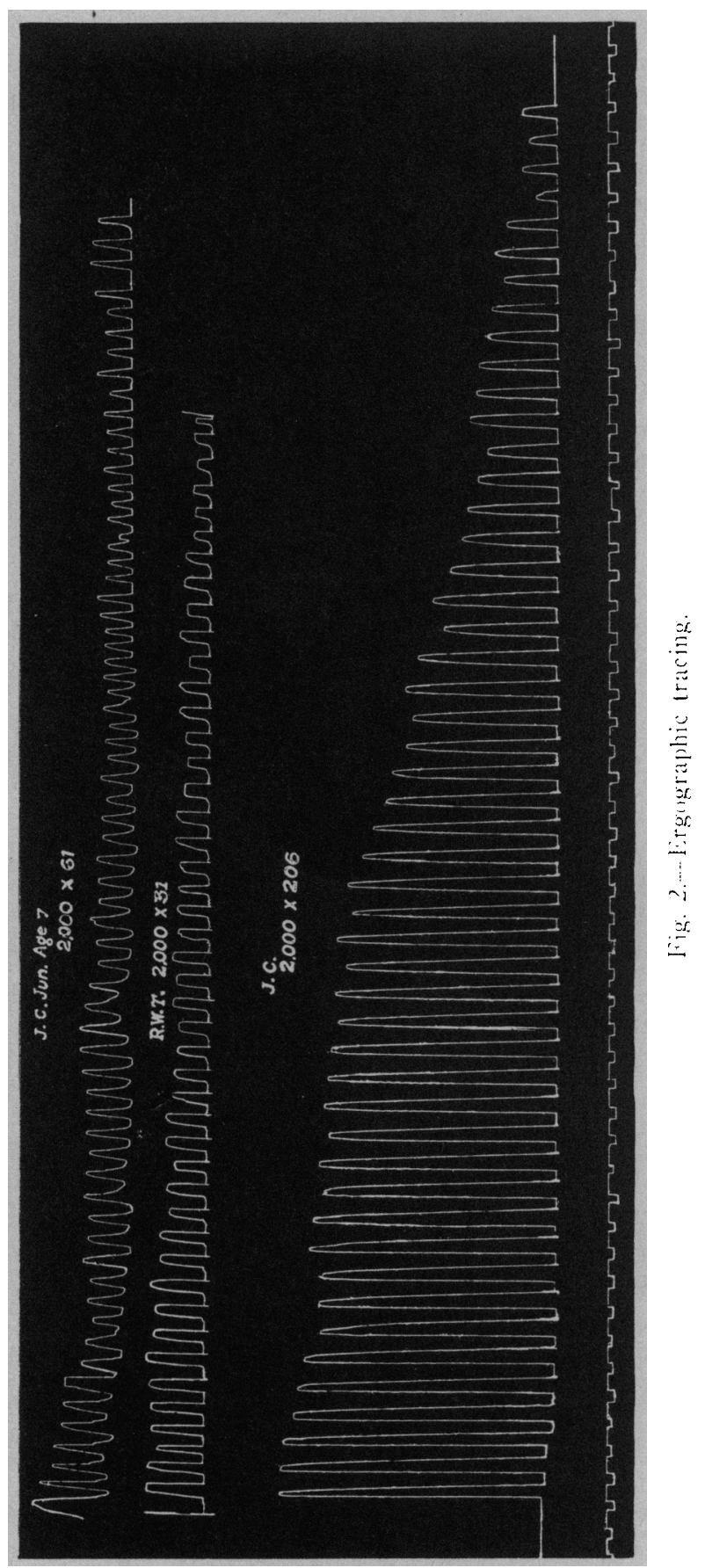

Downloaded From: http://archinte.jamanetwork.com/ by a Monash University Library User on 06/16/2015 
Table 7 shows a tracing of R.W.T., J.C., (the laboratory attendant), and J.C., Jr., the son of the latter, aged 7 years 2 months. With a load of 2,000 , the child has an excursion of 61 , as against R.W.T.'s average which is well under 40 . This child was still normally excreting creatin.

The observation on May 9, 1920, corresponds to a time when he had been taking thyroid, 15 grains, per day for about twenty-one days. The tracing of June 6 was taken on the last day of thyroid administration and showed a drop to 10 , the lowest recorded in the series. The dynamometer record on this day was 40 , so that the loss was in endurance rather than in power. On all grounds, therefore, the taking of thyroid produced undesirable results.

Table 7. - Ergographic Tracings of Patient and Two Normal Subjects

\begin{tabular}{|c|c|c|c|}
\hline Date & Name & Excursion & Dynamometer \\
\hline $5 / 9 / 20$. & R. W. 'I'. & 36 & \\
\hline $6 / 6 / 20$. & R. W. T. & 10 & 40 \\
\hline $6 / 10 / 00$. & J. C. & 249 & 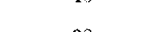 \\
\hline & J. $\dot{\mathrm{C}}$ & 21 & 38 \\
\hline$\pi / 2 / 20$. & R. W. $\mathrm{T}$. & 36 & 39 \\
\hline $9 / 12 / 20$. & R. W. T. & $\begin{array}{r}2-20 \\
39\end{array}$ & 40 \\
\hline $9 / 21 / 20$. & R. W. $\mathbf{C} \cdot 1$. & 930 & 89 \\
\hline $10 / 24 / 20$ & J. C., Jr. & 61 & \\
\hline
\end{tabular}

June 12 , six days after ceasing to take thyroid, a rise to 21 had occurred.

June 14 , the administration of pituitary was commenced, and a tracing taken July 2 showed the figure 36 , practically a return to the normal for him.

Before commencing strychnin administration September 13, a tracing was taken September 12 . The patient was feeling exceptionally well, and this was reflected in the number 39.

Strychnin was stopped September 20, and the following day the observation showed a drop to 26 . Throughout the whole experiment, the dynamometer record has varied very little; the ergographic tracings have given much more valuable information, revealing variations in total work capacity rather than in degree of effort.

In considering the diagnosis of this condition, one is at once met with the striking absence of pathologic signs, except the infantile degree and character of muscular power; and the presence of creatin in the urine.

On clinical grounds, the varieties of progressive muscular atrophy are inadmissible, inasmuch as the condition is not progressive, nor is there evidence of muscular atrophy. Myasthenia gravis, amyotonia 
congenita and pseudohypertrophic paralysis are mentioned merely to be dismissed.

What, then, is the condition? Is it a pathologic entity resulting from disease of or lack of development of some yart of the nervous system, or some of the endocrine glands, or is it some inherent variation in muscle tissue? No support is given to the latter theory by histologic examination of muscle tissue. The solution of the mystery is.closely bound up with the metabolism of creatin, regarding which many scattered pieces of evidence of variable trustworthiness are available, but regarding which no satisfactory evidence has been adduced of the source of supply or the mechanism of its transformation into creatinin. Creatin is normally present in young children and abnormally present in some pathological states. Why it should disappear as maturity is reached we do not know.

On the basis of clinical data, of ergograph and dynamometer records, and the presence of creatin in the urine, I venture to describe this as a case of muscular infantilism. Its ultimate cause is still unknown, and the condition is entirely uninfluenced as yet by treatment. Such observations as have been made tend to negative the suggestion that the endocrine glands are at fault. 